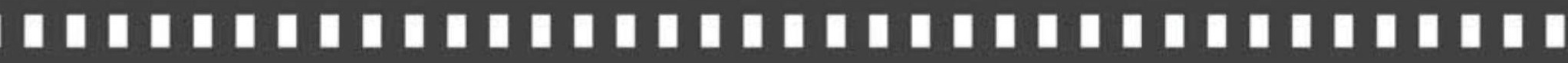 "iAmantes de papel!": \\ Las cupletistas y su performatividad a través de las postales fotográficas de las primeras \\ 口
}

Gloria G. Durán*

Miguel Molina-Alarcón**

Artigo recebido em: 17/11/2020

Artigo aprovado em: 15/12/2020 


\title{
“iAmantes de papel!": \\ Las cupletistas y su performatividad a través de las postales fotográficas de las primeras décadas del siglo XX en España
}

\section{"Paper lovers!": \\ The Singers of "Cuplés" and their Performativity through the Photographic Postcards of the First Decades of the 20th Century in Spain}

\author{
Gloria G. Durán* \\ Miguel Molina-Alarcón ${ }^{* *}$
}

\begin{abstract}
Resumen: Este artículo está escrito desde una perspectiva menos tratada de la "Historia con la fotografia" y pone en valor en las postales como dispositivo de memoria. Centra esta memoria en la constelación de cupletistas cuya performatividad generó infinitas postales que dieron pie a otros nuevos acontecimientos performativos en las casas, calles y estudios de pintores y escritores. Hablamos de ellas, de ellos y de las mujeres postales.
\end{abstract}

Palabras clave: Postal fotográfica, cuplé, performatividad, vanguardia.

Abstract: This article is written from the "History with photography", instead of "History with photography" and read postcards as memory devices. It centers these memories on the constellation of singers of "cuplés" whose performativity generated endless postcards that gave rise to other new

* Universidad de Salamanca, Universidad Complutense de Madrid, SUR-Escuela de Profesiones Artísticas.

${ }^{* *}$ Grupo de investigación Laboratorio de Creaciones Intermedia (LCI) Universitat Politècnica de València. 
214 “iAmantes de papel!": Las cupletistas y su performatividad a través de las postales fotográficas...

performative events in the houses, streets and studios of painters and writers. We talk about the singers, about them, the writers and painters, and about the final "postal women".

Keywords: Photographic postcard, cuplé, performativity, avant-garde.

\section{Introducción}

Algunas de las postales eróticas que vendian entonces [...] Recuerdo nítidamente una [...] La contemplaba cuando podía.

¡Las amantes de papel! (Eduardo Haro Tecglen, El niño republicano, 1996)

Fueron muchos más de 45 días y 30 marineros los que hicieron falta para que a Norah Lange, musa ultraísta bonaerense, se le ocurriera hacerse una fotografía a tamaño natural de un hombre cualquiera con la que casarse primero, acostarse después, para finalizar cuando se cansara, hacerla pedacitos para tirarlos al mar, enterrarlos o "repartirlo entre los amigos más adictos [...]" (LANGE, 2015 , p. 85), en todo un acto simbólico de divorcio express. Tuvieron que pasar muchos años desde esas fundacionales, y decimonónicas, piernas de la Condesa de Castiglioni (SOLOMON-GODEAU, 1986) que al mostrarse sin pudor avanzaron la posibilidad de enamorarse locamente de un trozo de papel con una imagen aparecida tras la magia de la luz y las sales de plata. Ese amante fugaz y aplanado se le ocurrió a Lange en 1927 y las piernas de la Castiglioni se hicieron famosas entre las décadas de 1860 y 1890 . Durante todo ese intervalo de tiempo las fotografías en general y las postales en particular 
fueron llenando un imaginario colectivo que en 1860 ni existía y en 1927 era de una riqueza y variedad inconmensurable. Miles y millones fueron las postales que transitaron, cual nueva república de las amantes voladoras, el espacio europeo. Sacos y sacos de imágenes postales (de $9 \times 14 \mathrm{~cm})^{1}$ llenaron todas las casas de correos de ciudades grandes y pequeñas, de pueblos y de aldeas. Las postales no solo fueron profesores temporales para una renovada educación sentimental, sino que también permitieron a sus protagonistas, a aquellas que aparecían allí retratadas, inventar mil modelos posibles para construirse como ciudadanas del mundo. Ellas que decidían y ellos que las coleccionaban dieron las claves para que en 1927 a Norah la imaginación le volase bien alto.

Cada una de esas postales se convertían en índices, huellas coloreadas de eventos vanguardistas. Además anunciaban nuevos eventos, en su libre circulación movilizaban públicos enormes. Todas cobraban vida en el cotidiano de las familias, se inmiscuían en los asuntos corrientes de las personas, se intercambiaban, se enviaban, se recibían, se coleccionaban o se guardaban en cajas especiales o en cajas olvidadas. Las postales tenían una vida mucho más allá de la fotografía y su índice. Eran un dispositivo de memoria, promotoras de la modernidad, rayos de luz de lo eterno que hay en lo transitorio. Portaban en su minúscula dimensión aventuras, desamores, pasiones ocultas, adelantos prohibidos, posibilidades no siempre al alcance de cualquiera, anhelos deseos y también olvidos. Instigaban la imaginación, las pasiones inconclusas, los amores

1 A finales del siglo XIX, la Unión Postal Universal reguló el formato de las postales. Se recomendó que sus dimensiones fuesen $9 \times 14 \mathrm{~cm}$. Ese es el formato de las postales antiguas, que se mantuvo hasta cerca del año 1960. Las postales modernas son un poco más grandes, midiendo alrededor de $10,5 \times 15 \mathrm{~cm}$. 
216 “iAmantes de papel!": Las cupletistas y su performatividad a través de las postales fotográficas...

imposibles, las vidas paralelas y las amistades peligrosas, como las postales eróticas o "sicalípticas" que circulaban de modo clandestino (SÁNCHEZ SÁNCHEZ; VILLENA ESPINOSA, 2010, p. 41-42). El hecho que la tarjeta postal tuviera como novedad comunicativa de "correspondencia breve al descubierto" (SÁNCHEZ SÁNCHEZ; VILLENA ESPINOSA, 2010, p. 11) generaba un debate si realmente "rompía el principio del secreto de las comunicaciones o no" (SÁNCHEZ SÁNCHEZ; VILLENA ESPINOSA, 2010, p. 24). Las postales atesoraban, y atesoran, todo un tiempo histórico que trasciende al individuo y habla de sociedades enteras. Por ello mismo, nuestro enfoque para abordar este "tiempo histórico", no nos interesa tanto desde la "Historia de la fotografía", donde el fotógrafo es el sujeto principal, sino desde una perspectiva menos tratada de la "Historia con la fotografía" (GONZÁLEZ REYERO, 2007, p. 42) de lo que la fotografía nos habla como "texto visual" y "vida performativa" de su contexto, tiempo, su circulación, vivencia..., ya que no solo son importantes quienes la hacen, sino también las personas que piden ser retratadas, en nuestro caso las cupletistas, y quienes las utilizan y viven con ellas, sean artistas y ciudadanos, es decir, la performatividad que generan las postales desde la toma fotográfica como acontecimiento performativo a su circulación por las casas, calles y estudios de pintores y escritores. Los actores principales ya no son exclusivamente los fotógrafos, sino especialmente en este caso las mismas cupletistas que se sirven de estas postales como parte de su acción performativa, que se suma a la acción de los ciudadanos que las circulan entre ellos y los artistas que componen con estas postales de cupletistas, auténticas "instalaciones" y "fotomontajes" en sus estudios y entornos de su trabajo. 


\section{Ellas. Las que aparecen en las postales}

Muchas de las postales que transitaban la Europa de la Edad de Plata eran de mujeres del mundo del espectáculo, creadoras contemporáneas, reinas de las variedades y de la vida urbana. Cada imagen de cada postal surgía tras un acontecimiento. Por ejemplo cuando Helena Cortesina, en septiembre de 1920, se va a la Playa de San Sebastián vestida de Fântomas ante el asombro de los bañistas, ya había contratado a un fotógrafo para hacer una tirada de postales, que se vendían después a centenares y por todo el país. Estaba el público que la miraba anonadado sin entender lo que encerraban esas mallas negras adheridas a ese esbelto cuerpo despistado y sensual.

Fig. 1 - Fotografía de Padró: Helena Cortesina con traje de Fântomas en la noticia: "La nota de sensación en la playa de San Sebastián".

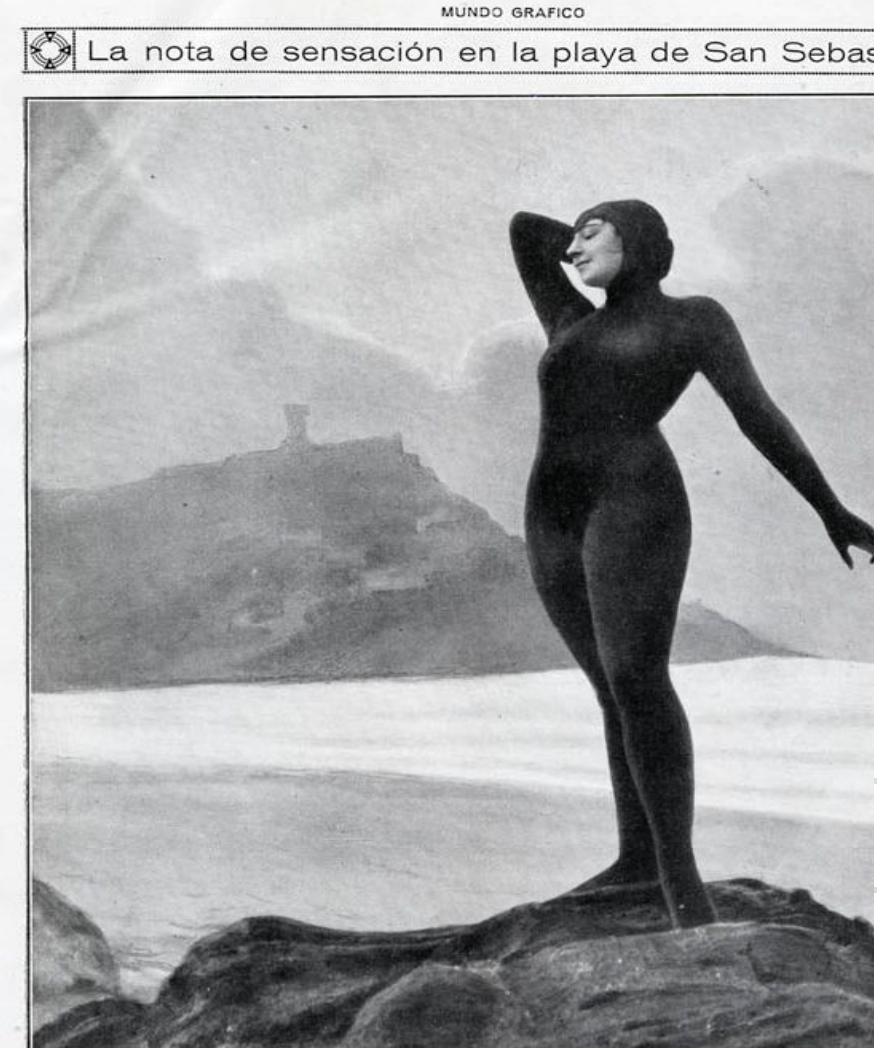

Fuente: Archivo Kutxa Fototeka [1920]. 
218 “iAmantes de papel!": Las cupletistas y su performatividad a través de las postales fotográficas...

Fig. 2 - Fotografía de Martin Ricardo: Helena Cortesina de Fântomas junto a los bañistas de la Playa de la Concha de San Sebastián, 1920.

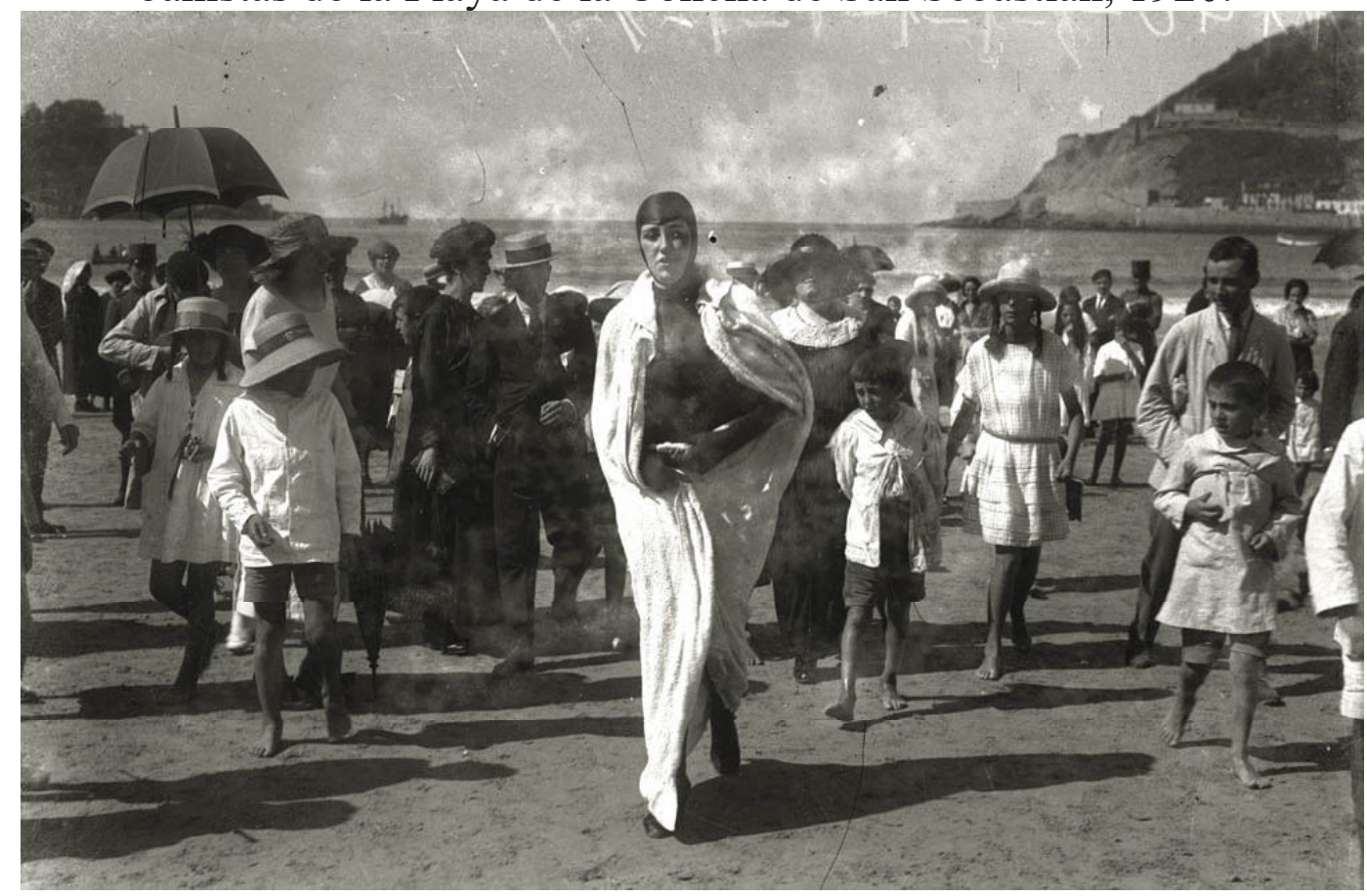

Fuente: Mundo Gráfico (1920, 8 sep.).

Todos los periódicos del momento, de hecho, se hicieron eco de lo que la misma Helena construyó como estelar noticia. Un auténtico acontecimiento en las frescas playas del mar Cantábrico. La sorpresiva aparición cual mujer vampira y el principio de una campaña de marketing en toda regla:

La hemos visto en San Sebastián bañarse con su traje de Fântomas, con guantes y zapatos. La Venus de ébano, como allí la llamaban, ha sido la figura del día en la playa donostiarra, y señoras y señoritas, jóvenes y viejas, pugnaban por lograr un buen puesto en la Perla, para ver cómo salir a bañarse la Venus valenciana. Es incalculable el número de placas fotográficas que han impresionado con La bella figura de esta danzarina fotógrafos y aficionados, y las postales editadas han sido vendidas por centenares. Un periódico que publicó su fotografía con el raro bañador que ha puesto de moda Elena dice de ella lo siguiente: 
«Tan exacta de líneas como la de Milo, ni Fidias se hubiese desmerecido a sí mismo habiéndola plasmado en su Partenón, ni Praxiteles hubiera dejado de trasladarla a sus mármoles inmortales, si la conociese. Evoca su contorno toda la plasticidad hermosamente profana de las vírgenes romanas sacrificadas a Cesar y en el titilar palpitante de sus carnes de diosa se ve la vida exuberante y erótica de todos los gestos del espasmo. Elena Cortesina, la virgen bruna, tiene el deleite de bañar su cuerpo en el mar, y como la Helena de los griegos, parece ser la inspiradora de su paganos ritos y adoraciones. (17 de septiembre de 1920). (LA CORRESPONDENCIA DE ESPAÑA, 1920).

Helena no era cupletista, era actriz, e incluso directora de cine y en los años 20 ya habían aprendido mucho de cómo transformarse de anónima mujer trabajadora en estrella del firmamento de la farándula. Pero las grandes magas del arte de la explotación de una postal para autopromoción y venta serán sus antecesoras las cupletistas, infinitas estrellas de un grandísimo firmamento. Desde finales del siglo XIX hasta que estalló la Guerra Civil Española las imágenes de las cupletistas, o cantatrices, creadoras, que llenaron las tablas de cada rincón del país acababan atrapadas en los cartoncitos de colores que circularán de lugar en lugar. De hecho las postales fueron claves para el sistema del cuplé. Las cupletistas, empresarias de sí mismas, hubieron de inventar su personaje público y congelarlo en mil imágenes que hablaban del acontecimiento de cuando se crearon y de la protagonista de ese mismo acontecimiento, "producirse como imagen" (CLÚA, 2016, p. 75-91). Luego ya posadas en su cartoncito volaban como piezas de mail art popular y masivo de hombres mayores y jóvenes, viejos verdes y púberes enamoradizos, casadas felices y casadas frustradas, lesbianas ocultas, viudas tranquilas, 
220 “iAmantes de papel!”: Las cupletistas y su performatividad a través de las postales fotográficas...

niñas listas y lentas, solteras empedernidas, empleadas del hogar, damas, cuñados y porteras.

Figs. 3 y Fig. 4. - Tarjeta postal circulada (anverso y reverso) de la cupletista Bella Chelito interpretando el cuplé "La pulga".

Tarjeta postal editada por LB (Lluis Bartrina), Barcelona, sin fecha.
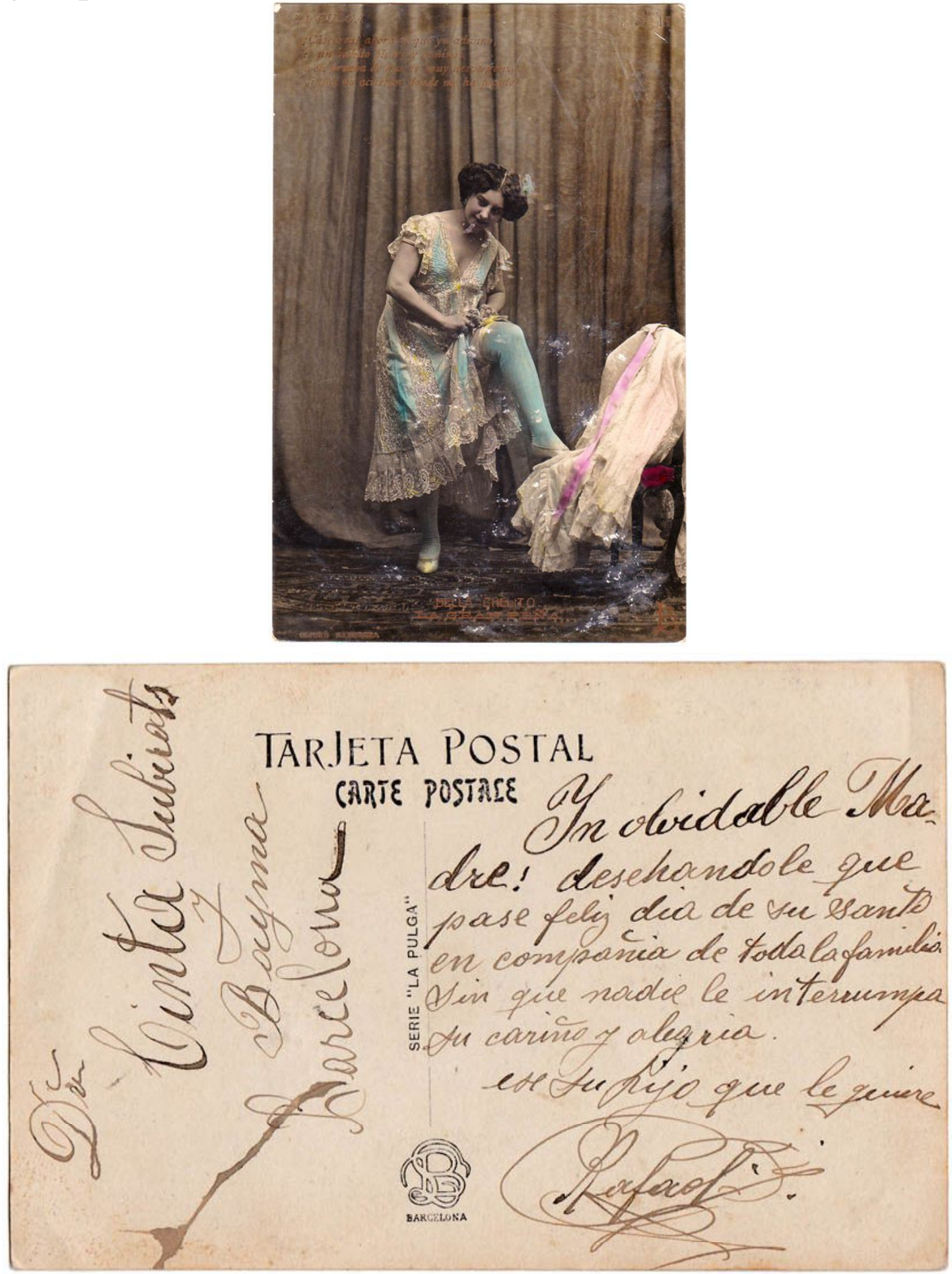

Fuente: Colección particular. 
La magia de las imágenes residía, precisamente, en su silencio. Nos estábamos desperezando sí, pero las precauciones nunca fueron suficientes. No importaba lo insinuante de las imágenes, lo sicalíptico y picante de la fotografía y de la fotografiada, siempre se empleaba un lenguaje telegráfico, frío, distante y correcto. Por ejemplo, en la parte posterior de la postal más lúbrica y sicalíptica de La Chelito², cuando se busca furiosa "pulga maligna" entre su ligerísima ropa interior de 1908, un tal Rafael felicita a su mamá con estas notas en letra cursiva e inglesa, con algún error de ortografía: "Inolvidable madre! desehandole [sic] que pase feliz día de su santo en compañía de toda la familia sin que nadie le interrumpa su cariño y alegría. Ese su hijo que le quiere. Rafael".

Todas las protagonistas de las postales, La Chelito y las demás, fueron creadoras en la escena, con su particular modo de hacer cada cuplé como pieza única y propia y también fueron creadoras de un ser único e irrepetible, un modelo original y propio. Todas las estrellas tenían su parcela de gloria en todos los estudios de fotografía, que surgían de manera exponencial, en esa Edad de Plata. La Fornarina, Julita Fons, Amalia de Isaura, Mercedes Serós, La Cachavera, todas las Bellas: La Bella Alit, Bella Belén, Bella Chelito, Bella Chiquita, Bella Diana, Bella Dorita, Bella Emilia, Bella Florido, Bella Leonor, Bella Marujilla, Bella Monteverde, Bella Otero, Bella Tortajana, Dolores Abril, Balbina Albalat, Pilar Alonso, Carmen Andrés, María Antinea, La Aretina, y muchas más. Una constelación de cupletistas (que llamaran los Álvarez Quintero) quizá más incluso de las 466 que nombra Álvaro Retana (1964) en su Historia del Arte Frívolo, todas 2 Consuelo Portela, conocida artísticamente como La Chelito (Cuba, 1885 Madrid, 20 de noviembre de 1959) fue una popular cantante española de cuplé de principios del siglo XX. 
ellas, aprovechaban y explotaban las posibilidades de publicitar su imagen en tarjetas postales, para darse a conocer y para inventarse como Nuevas Mujeres. Nuevas incluso para sí mismas.

La amenaza de esas estelares figuras, de esas mujeres capaces de construirse a sí mismas no se refería solo a su hiper sexualización, sino que también se referían al modo en el que lograban desdibujarse, hacerse imprecisas, ser mitad ángel y mitad demonio, mitad mito y mitad virus maligno. En la invención de sí habían de cuidar cualquier aparición, que debería ser algo imprevisible e impresionante. Habían de elegir cuidadosamente los posados, los vestidos y los peinados de las postales con las que se daban a conocer. Todas estas imágenes en cartón se distribuían masivamente y debían resultar seductoras y evocadoras. Ahora bien, esta oda de lo evocador y lo seductor permitía jugar. La sociedad empezaba a consumir imágenes sin parar, y las de las estrellas del cuplé, del cine y de las tablas, eran las más deseadas y codiciadas. Así que ese deseo y esa necesidad de autopromocionarse crearon un contexto experimental, un nuevo campo de juegos donde mostrarse y esconderse en otros personajes de sí mismas. Podían, y solían, desdoblarse, generando variados sentidos a su misma condición y en ese desdoblamiento, tremendamente dandyficado, el catálogo de posibilidades de construirse como mujer se ampliaba ad infinitum y el carácter de mascarada se reforzaba. Esta mascarada, huelga apuntarlo, se hizo muy amenazante. Mujeres de contornos difusos serán siempre peligrosas. Las heroínas de la modernidad haciendo ciudad mutante.

La Bella Otero es una de las más impresionantes. Es un auténtico arsenal de personajes y personalidades. Todas las fotografías y postales que circulaban por Europa le servían para su permanente 
promoción y venta. En casi todas aparece embutida al vacío en las mallas color carne tan clásicas del momento. Ahora bien, cuando le preguntaban en 1890 sobre sus recursos y métodos para construirse, afirmaba que todo era natural:

"La gente me pregunta qué hago para tener la cintura tan fina. Yo respondo: nada. Es natural. Es mi constitución. Para mí sería igual de fácil bailar sin corsé, y lucirla igual de bien [...] De hecho, en verano siempre bailo sin corsé. La gente cree que es difícil. Pero es mucho más fácil y me gusta más”. (CLÚA, 2016, p. 116).

Figs. 5 y 6. - Bella Otero como Reina de Picas de la baraja. Edición: C. Jeangette, éd. París, 1904.

y Tarjeta postal circulada de Caroline Otéro [Bella Otero]. Foto: Reutlinger.
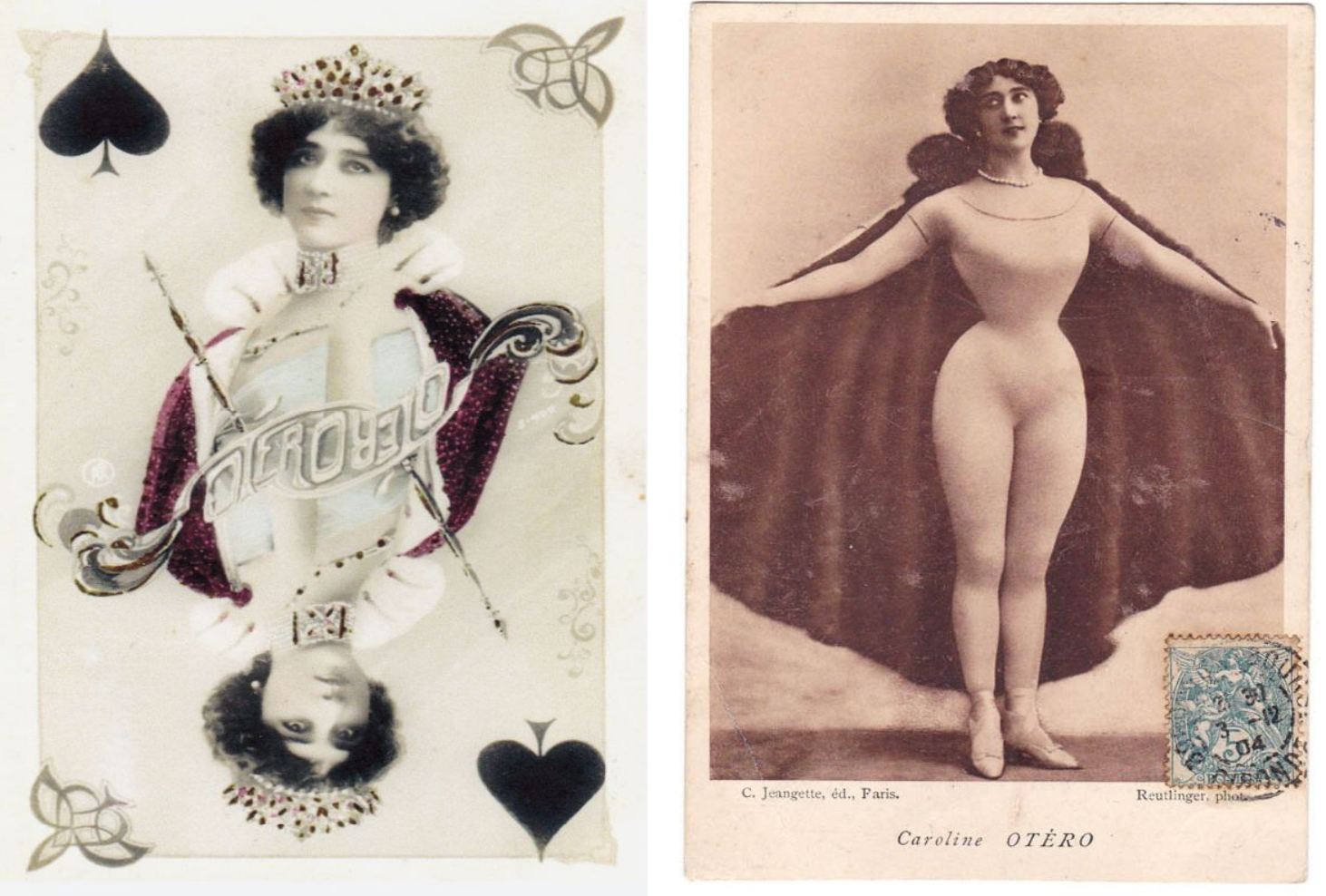

Fuente: Colecciones particulares.

La Otero sería la creación del mainstream, rebelde pero comprensible. Pero la rebelde más exquisita con belleza 
vanguardista y renovadora de la misma idea de belleza femenina será sin duda su contemporánea Polaire. Mlle. Polaire, cuyo retrato habían popularizado ya a finales del siglo XIX las cajas de cerillas y las tarjetas postales, era muy amiga de Rachilde, de Colette y de Willy, los tres escritores muy sicalípticos y muy reconocidos en la vanguardia parisina y, por ende, también en la europea. En sus memorias, Polaire par elle-même (BOUCHAUD, 1933) se describe pormenorizadamente a contracorriente de la Bella Otero. Su éxito radicaba en sus "peculiaridades anatómicas" que ella exaltaba para lograr el efecto deseado: "Yo soy-dice a quién quiere oírla Mlle. Polaire- la actriz más horrible que ha pisado los escenarios. Tengo ojos de buey, boca de pez, talle de sílfide y pies de ogro" (La cantante más fea del mundo. Interesantes declaraciones de Mlle. Polaire, Revista Alrededor del Mondo, n. 304, p. 201, 30 de marzo de 1905). (LA CANTANTE..., 1905). 
Figuras 7 y 8. - Tarjeta postal circulada de Polaire sacando la lengua (s. f. y Polaire con un piercing en la nariz publicada en la prensa, 1913.
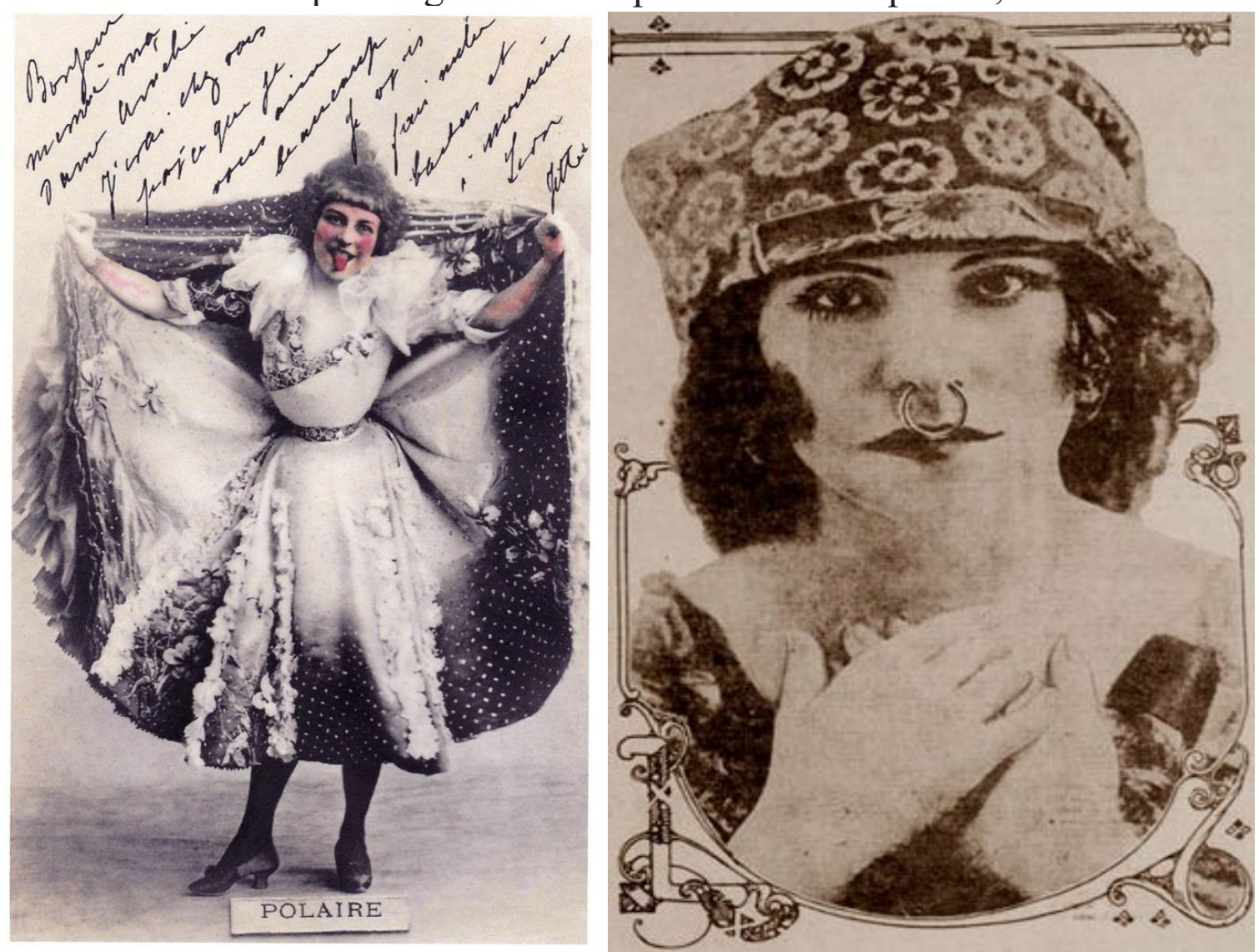

Fuente: Colección particular. The San Francisco Call, 17 de septiembre de 1913.

Otra renovadora y amplificadora de la idea de belleza para la mujer por venir, ya en el siglo XX y en sus tumultuosas primeras décadas, fue Yvette Guilbert quien también de modo muy consciente modelará su presentación pública única y específica diseñada, decidida y prevista. Apuntalada con postales, entradas de prensa, declaraciones y argumentos varios de los comentaristas. "Fue", diría Yvette Guilbert en sus memorias, “cuando trabajaba en el Café Edén que planeé hacerme una silueta que contrastara con todo lo que se había hecho hasta ese momento, que fuera nueva y diferente". Una silueta y una imagen con la que no solo cantaba en el Edén o en El Dorado o en el Ambassadeur, sino que también posaba para su 
promoción. No se movía casi, representando un momento epiléptico previo al colapso. Sus ojos parecían perderse en un lugar remoto, miraban tan hacia arriba que el público los veía en blanco. Hacía gestos descoordinados con sus larguísimos brazos, sin mover el tronco, su estilizada figura parecía sostenerse de milagro y su cara caía hacia abajo como si tuviera muchos más años, lánguida y deshuesada.

Ya lo advirtió Ramón Gómez de la Serna, en su libro Ismos, donde ponía en valor lo cómico, lo mágico, lo irreconocible, lo novísimo, de todas esas nuevas imágenes y sus performatividades:

De la mezcolanza de unos con otros y sus doctrinas brotará la palingenesia del arte nuevo, el horóscopo para entenderlo; entendiendo por arte nuevo esa mezcla de literatura, pintura y demás músicas. Influyó en el arte nuevo desde la figura escuálida y pálida con largos guantes negros, de la Yvette Guilbert, hasta las muecas de la ancha boca de la Polaire. (GÓMEZ DE LA SERNA, 1931, p. 8).

Este nuevo arte, o arte nuevo, emana de la fuerza performativa que subyace, y es necesaria, para cada una de las imágenes que poblaron las vidas de los otros.

En el artículo, "Representing Awarishness: Burlesque, Feminist Transgression, and the 19th-Century Pin-Up" de MariaElena Buszek (1999), se define este término, awarishness, tomar conciencia, be aware, darse cuenta, hacerlo a propósito. A conciencia, intencionadamente, on purpose. Pepa Anastasio (2009) en su artículo Pisa con Garbo. El cuplé como performance, dice que la representación de las cupletistas y demás damas de la farándula, las 
varietés y las tablas europeas y americanas, llevan a cabo una auto construcción que implica la repetición de unos gestos y atributos genéricos que son reconocidos en su contexto. Añade,

Como muestran las postales que circulaban a manera de carte de visite para promocionar a las artistas, el catálogo de posturas, poses y vestuario es variado; sin embargo un rasgo común de estas postales es lo que Maria Elena Buszek, en un contexto similar al del cuplé, ha llamado "awarishness", esto es, una actitud a través de la cual las artistas crean un espacio desde el que podían construir, controlar y promocionar su persona escénica (ANASTASIO, 2009).

Todas ellas eran ciertamente incómodas para la sociedad, no solamente porque salían al escenario y actuaban su provocación sensual, sino, y precisamente, porque eran conscientes y conocían la potencialidad de su puesta en escena sexualizada. Esta, les proporcionaba una grieta, un hueco de incorrección admitida (por el bien del pueblo), en el que experimentar infinitos modos de ser y estar (BUSZEK, 1999, p. 43).

El pequeño giro en la palabra añade al "darse cuenta" una capa de repetición que nos viene bien para entender el poder subversivo y performativo de esta escurridiza, aunque conocida, puesta en escena. Judith Butler (1998, p. 296-314) nos hace apercibirnos precisamente de lo impredecible de la asunción de esta tergiversación en los gestos. Es posible entender que la repetición de esos gestos que constituyen la performance de la cupletista, tanto en las postales como en el escenario puede tener algo de subversivo. No importa que la intención no sea esa, lo que le imprime el carácter subversivo a un performance no es la intención. Tal y como la performance de la mujer, como 
debe de ser, repite un guion preestablecido, las performatividades subversivas inventan los guiones permanentemente (DURÁN, 2011). De ahí el miedo social, que se mezcla con la fascinación, de estas amantes del papel. Nos cuenta Anastasio como la recepción de muchas de ellas era paradójica, admirada y temida. Hasta un padre nuestro dicho por una de ellas parecería un absoluto atentado al pudor.

Todas las amantes de papel, las celebridades de la era victoriana, como lo serán las famosas cupletistas españolas, no eran toleradas y sí muy admiradas. Una paradoja constitutiva de su naturaleza indómita que las ha lastrado, todos las desean, nadie confiesa tal deseo amparados en la corrección. Eran símbolos de la autosuficiencia e independencia de las mujeres, pero como tales eran doblemente amenazadoras: al igual que las clases medias en general, abogaban y encarnaban el trabajo duro, la educación, la cultura y los lazos familiares, pero a diferencia de las prostitutas, eran consideradas como vasos "apropiados" de belleza física y sexual y legítimamente conmovida en la sociedad como seres atractivos y deseables. (DAVIS, 1991, p. 69).

\section{Ellos. Las coleccionan y las pegan en sus paredes}

En 1973 José Altabella escribió una suerte de oda a la Belle Époque en un artículo de prensa dedicado a la cupletista Julita Fons en el año en que murió. Su artículo "El último día de reyes de Julita Fons. La primera figura de la Belle Époque fue la reina de nuestra revista hasta 1927", recuerda un Madrid picaresco y galante, en el que la cupletista incendiaba en amor las bambalinas y las postales, con su 
imagen en colores chillones. Recuerda cómo esas mismas postales servían para señalar los libros galantes y sicalípticos de Felipe Trigo, de Insúa, de Zamacois y de Hoyos y Vinent. Julita estaba en la vida de muchos jóvenes, y no tan jóvenes de ese Madrid que se fue. Fue como una reina, y fue viciosa del éter y se curó con la literatura de Lorraine y de Guido da Verona. Las postales aparecían pues también en la lectura, esa doble evasión, enredado en las palabras y en las insinuantes poses de Julita, sensual y cercana. Republicana declarada será regada y regadera, gatita blanca, Salomé y Cleopatra, y luchadora grecolatina, ciclista por un día y examinadora paciente del alma de los elefantes.

Muchos escritores decían sólo conocer a las bellas cupleteras, cancioneras, actrices y creadoras, gracias a las imágenes reproducidas en postales, cajas de cerillas o linotipias. La "cartomanía", como patología social, era moneda común. Lo habitual es que todo el mundo, hombres, mujeres y niños, tuvieran, incluso coleccionaran, miles de tarjetas postales. La tarjeta postal. Estética e historia de Alfonso Pintó (1953) es un libro dedicado a "todos los seres cuya sensibilidad pueda percibir la delicada poesía de esas mensajeras del sentimiento"3. Ese libro dedicado a esas almas, que el año 1953 eran 3 Otro libro a destacar es el de Alfonso Pintó (1953) La tarjeta postal. Estética e historia, (Producciones Editoriales del Nordeste, Barcelona). Es un libro ilustrado con 60 grabados y dos tricomías. Hace una catalogación de las postales muy interesante: postales de elegancias, patrióticas de inglesas y francesas, postales de cupletistas españolas, postales pasionales, postales con relieve, con telegramas, con purpurina, panorámicas, de cine, de pintura, postales compuestas, de recuerdo, de inventos modernos, de retratos con espejos, de niños con animales, postales bordadas, postales modernistas, postales de ingenios mecánicos con resortes, postales de enamorados, postales de danza, postales sentimentales, postales de cortesanas, y postales románticas. También las hay fluorescentes, de mitología, de varietés, de atletas y gimnastas, orientales, de lazos y espejos, de toreros, de flores y animales, de marinos, de escultura, especiales, y de ballets russes. 
230 “iAmantes de papel!”: Las cupletistas y su performatividad a través de las postales fotográficas...

muchas, indaga la naturaleza variopinta de la postal en el mismo año que Zúñiga publica Una historia del cuplé (1954). Cupletistas y postales van, ya se ve, de la mano. Las mensajeras del sentimiento rozan la más apabullante cursilería en muchas de las ocasiones, pero en otras tantas se transforman en poderosas armas de construcción masiva. Las postales suelen necesitar otras postales próximas para acabar de decirnos lo que tienen que decirnos. Mucho antes de que el dadaísmo pusiera juntas mil imágenes de diversos lugares recomponiendo nuevos significados mutantes, ya los coleccionistas de postales las ponían unas junto a otras. Inspirados además por la costumbre de los periódicos del momento de hacer collage con las caras de las damas más afamadas, cancionistas y actrices, gentes de sociedad y reinas, fueron muchos los que recompusieron su espacio de trabajo plagándolo de tarjetas postales, de fotografías y de imágenes varias de mujeres fotografiadas, pintadas y dibujadas.

Tanto hombres como mujeres conservaban y miraban a sus heroínas de los tiempos modernos ancladas en sus paredes. De hecho podemos decir que serán precisamente estas imágenes las que organizan la entrada en la modernidad. Lo que Abigail SolomonGodeau llama "la cultura de la cámara", establecerá la cultura del espectáculo, como lo nombrará Guy Debord y su pandilla situacionista.

José de Zamora [Pepito Zamora], el figurinista, figura él mismo, que paseaba con abrigo de señora por los bajos fondos de Madrid agarrado del brazo del inmenso Hoyos y Vinent, escribió su serie de artículos Cuando Madrid era pequeño (1955-1956), donde en uno de ellos relata que muchas de las cupletistas solo las había conocido "en las colecciones de fototipias de las cajas de cerillas a 
diez céntimos, que yo coleccionaba con el entusiasmo de un Lázaro Galdiano incipiente" (DE ZAMORA, 1955, p. 23). Esta pasión coleccionadora estaba más que generalizada. La impresión y las fototipias de cajas de cerillas y cigarrillos eran infinitas. Como las postales, la publicidad también dejaba entrever la imagen decidida controlada de cada cupletista. Eso sí, cual pretéritas influencers habrían de ajustarse al mensaje del producto comercializado y fingir su extraordinaria calidad.

Ramón Gómez de la Serna escribía en las revistas sicalípticas y era uno de los muchos ciudadanos que padecieron el mal de la cartomanía. Su famoso despacho estaba cubierto de suelo a techo de imágenes de todo tipo. Hay de todo, postales, recortes, objetos. Él tuvo dos estudios, en Madrid y Buenos Aires. El de Madrid (su "Torreón" de la Calle de Velázquez) era una gruta, hasta el techo estaba completamente cubierto de fotografías conjuntadas al azar, que llamó "estampario" ['relicario de estampas'] o "fotomontaje monstruo" por su gran dimensión que llegó a crecer entre 1922 y 1936, y también porque según Ramón lo hizo antes de "la gran moda de los pequeños fotomontajes", aunque reconoce sus antecedentes como la de una "bella dama parisiense" que empapeló su gabinete con las cartas de amor recibidas de sus "pretendientes desdeñados" (GÓMEZ DE LA SERNA, 2018, p. 361). Su recorrido para verlo lo planteaba como una invitación performativa al visitante de "Un viaje alrededor de mi cuarto" (GÓMEZ DE LA SERNA, 2018, p. 361-370), que para él era un "¡Arduo viaje este viaje tan corto!” y de "muchos kilómetros qué hacer [...]", preguntándose muchas veces sobre sus propias imágenes de lo que significaban y cuando terminaba este viaje cansado y mareado, se preguntaba, cosas como 
232 “iAmantes de papel!”: Las cupletistas y su performatividad a través de las postales fotográficas...

"¡Donde vimos una fuente que era una dama con paraguas que echaba el chorro de agua por la contera del paraguas?" (GÓMEZ DE LA SERNA, 2018, p. 370). Para él, que una fotografía o postal acabe en un cajón, álbum o en el rastro era un "desahucio" a la vista de la memoria humana (GÓMEZ DE LA SERNA, 2020, p. 85), por eso quiere darles una nueva vida a la vista en sus paredes, techos, puertas y ventanas, donde se yuxtaponen con otras fotografías y grabados, creando "peregrinas" relaciones entre "medusas y las bocas" o entre “las manos y los cactos” (GÓMEZ DE LA SERNA, 2020, p. 331).

En sus paredes había también tarjetas postales de cupletistas, incluso escribe un artículo sobre "Postales bordadas", 1927, con el vestuario bordado de hilo de oro y lentejuelas de las cupleteras, que las enviaba al extranjero y le contestaban enseguida entusiasmados gritando “¡Viva España!” (GÓMEZ DE LA SERNA, 2020, p. 254). Estamos convencidos que también tendría alguna postal de su admirada y promovida Chelito, que debía andar por ahí en sus paredes. La Chelito será quien reciba de parte de Ramón Gómez de la Serna las más elogiosas palabras. La creadora cupletista será para él una compañera, esa en la que "los modestos y tímidos escritores veían como compañera de luchas contra el oscuro presente", el de la entrada en el siglo XX. De hecho se conserva una fotografía de La Chelito en una tertulia del Café Colonial, el lugar en el que se fraguó parte de nuestra ultraísta vanguardia. La imagen que se proyecta da cuenta de una unión más ligera y libre entre cupletistas y escritores, una vida cotidiana capitalina muy diferente a la que nos han contado. Una noche de octubre de 1912 La Chelito andaba dando un paseo por la Puerta del Sol con un despampanante sombrero, Enrique Nieto de Molina (1912, p. 6) tras escuchar su llamada de "voz argentada 
como trino de cristal," la vio y le estrechó su "enguantada mano de azucena, toda alba y menuda". Siguieron caminando juntos, ella quería un par de cuplés, él quería llevársela al Café Colonial, a una tertulia sobre arte. Acabaron juntos y posaron para la posteridad empujando a una perezosa España hacia la modernidad.

Figs. 9 y 10 - Estampario en el techo, paredes y puertas del despacho de Ramón Gómez de la Serna en Madrid (izquierda) y en Buenos Aires (derecha)

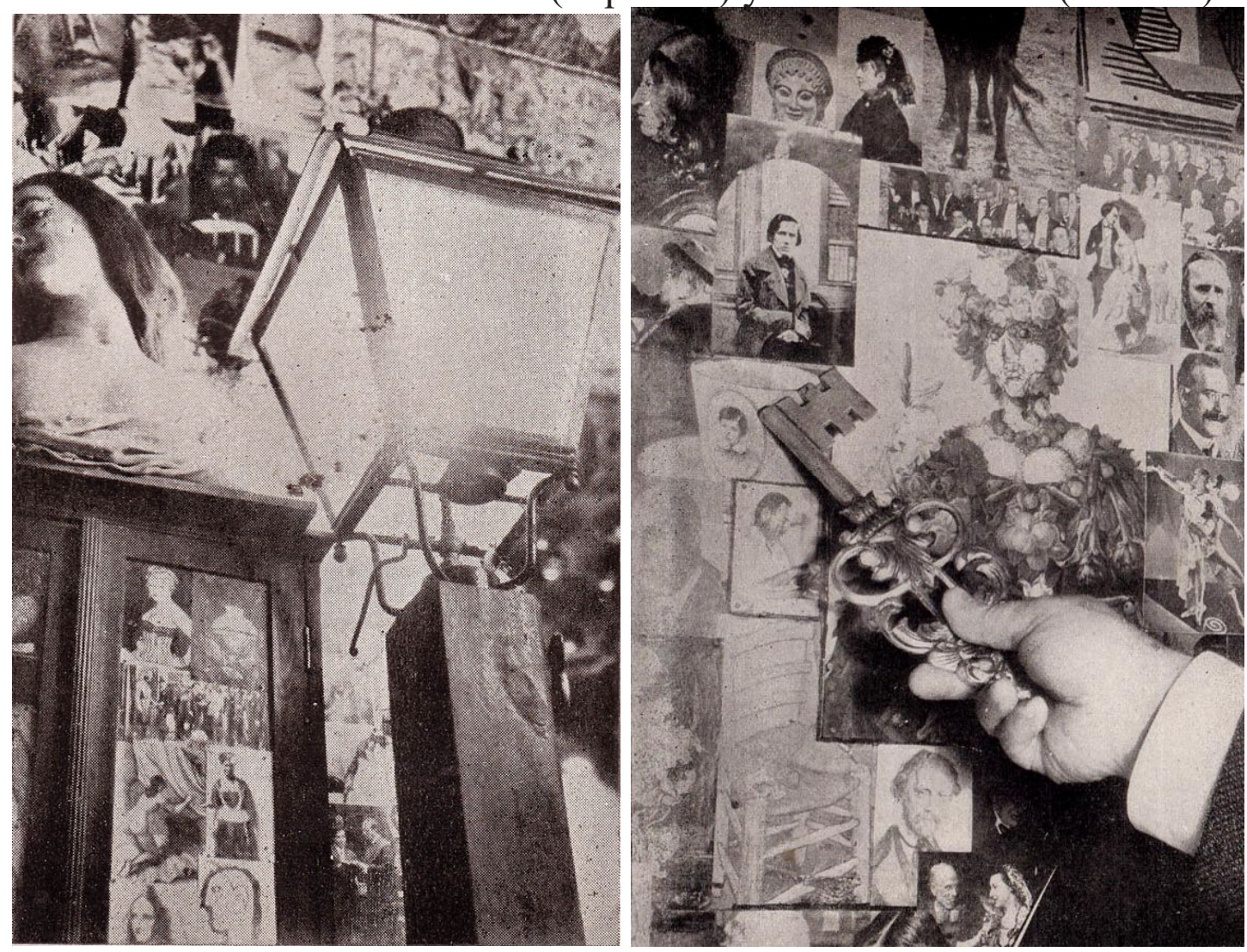

Fuente: Gómez De La Serna (1948).

Todas las chelitos de ese tiempo "iban a romper paredes de aburrimiento y espesuras y alentaban a la familia con entusiasmo ditirámbico" (GÓMEZ DE LA SERNA, 2002, p. 197) a decir de Ramón. Esos a los que las cupletistas iban a acompañar serán, en principio, algunos de los escritores de la Generación del 98, quienes en la pequeña tertulia del periódico El Globo, en la casa del padre de 
234 “iAmantes de papel!": Las cupletistas y su performatividad a través de las postales fotográficas...

La Chelito, promovieron su debut en 1902 en el Paris-Salon, gracias a un contrato conseguido por Azorín. Con el tiempo se unirán a sus contemporáneos más tendentes a la vanguardia, como Picasso que la dibujó varias veces actuando y en su archivo aparecen algunas postales de ella. Para Gómez de la Serna la gracia de La Chelito tenía el ritmo que correspondía a la sincera "alborada de un siglo, un ritmo de mayor despertamiento y con más audaz quererlo decir todo" ( $p$. 198). Con un modo de escritura muy ramoniano ese quererlo decir todo acompañará a los escritores, letristas, músicos, poetas y demás hombres de vanguardia en toda la Edad de Plata.

Sin embargo, como suele ocurrir, fueron las mujeres las que, no es que quisieran decir, sino que decían realmente, lo decían todo. Subían a los escenarios cual constelación y hablaban de lo que sucedía en las calles, de los problemas en la vida íntima, de su sexualidad, del precio de los alimentos, de la incompetencia manifiesta de los políticos, de su novios vagos y maleantes, de los cambios de roles en la vida íntima, de la modernidad de las calles, de los miedos burgueses a su despampanante libertad. Desde este debut fundacional de 1902 en el París-Salon de la calle Montera relatado por Gómez de la Serna en su biografía de Azorín, todas las chelitos serán la avanzadilla de esa innovación en el ritmo urbano que comenzaría al alborear el siglo y serviría de constante telón de fondo para todos los demás, ya sean cubistas, futuristas, ultraístas, creacionistas, suprarrealistas, realistas, surrealistas, o automovilistas parodistas. Esas postales de las que venimos hablando aparecerán como signo inequívoco de su trascendencia social en todos y cada uno de los altares, o lugares de trabajo, en los que poetas, letristas y artistas en general pasaban sus tardes y sus vidas. Mucho tiempo después el periodista Eduardo 
Haro Tecglen (2000, p. 30), recordará como de niño contemplaba estas postales como: “iLas amantes de papel!”. Quizá fueran eso, amantes de papel para toda nuestra vanguardia que aún era misógina y machista. De hecho con perspectiva podemos afirmar que eran modernos solo a medias, con la honrosa excepción de Álvaro Retana que cuidó, admiró y respetó a las mujeres, sobre todo a las de vida alegre.

Ángel Zúñiga también habló de esas postales coleccionables de damas inalcanzables para jóvenes imberbes. Zúñiga escribió uno de los acercamientos a ese Madrid del cuplé más vívidos y claros (ZUÑIGA, 1954). En las paredes de su casa de niño, además, colocaba las postales con caras de mujeres bonitas, Cleo de Mérode, la que puso de moda el peinado renacentista; la Bella Otero, la más famosa horizontal; Rosario Guerrero, la belleza española del cambio de siglo; las hermanas Conesa: una asesinada por celos con tan solo 16 años. La otra, María, emigrada y triunfadora en México; Anita Delgado, la marajá de Kapurtala; Sarah Bernhardt, pionera, coja y grandísima Sarah; Saharet, la bailarina del baile de la mariposa a quien grabara Alice Guy; La Bella Oterita; La Bella Dora; Teresita Calvo; la Tortajana... y miles más. Las casas de la clase media con las paredes repletas de bellezas contemporáneas atrapadas en postales. Ángel Zuñiga vivió entre 1911 y 1994, dedicó toda su vida al mundo del espectáculo, fue corresponsal en Nueva York de La Vanguardia.

Álvaro Retana era de esa pandilla de indeseables best sellers y epatantes modernistas del momento, dijo de sí mismo que desde su más tierna infancia había vivido para, con, de, en, sobre, tras la mujer. Niño precoz, a los trece años se dejó seducir por una opulenta jamona rubia y sentimental, madre de un compañero de colegio, y 
que el año diez y seis ya era amigo y confidente de La Goya, Adelita Lulú, Preciosilla, Tórtola Valencia, Amalia Molina, Chelito, Olimpia d'Avigny y otras deidades no menos celebérrimas en el mundo del arte o la galantería. Cierto es que su vida de letrista y frecuentador de los bajos fondos ocurrirá a principios del siglo $\mathrm{XX}$, ese tiempo sicalíptico en extremo. Continúa su disección afirmando que nunca se limitó a una atracción carnal por sus amigas las cupleteras, sino que será una atracción de alma y de los repliegues de sus corazones. Insiste en su odio atroz a las mujeres aburridas e irreprochablemente honradas y decantándose por las que muchos consideran "pérdidas" que suelen ser, insiste el sicalíptico autor, las únicas que realmente se han encontrado a sí mismas.

Álvaro Retana, el sumo pontífice de las variedades, será el mayor coleccionista de las imágenes que la constelación de cupletistas diseñaron para la posteridad. Creó su propio altar laico donde las cupletistas aparecían en sus postales como deidades supremas. En el prólogo de su novela El Tonto (1925), confiesa tener en su finca ese altar laico tapizado de terciopelo rojo y adornado con candelabros de plata y floreros de cristal. Presidiendo el altar se encontraba él mismo en calidad de dios mayor, y a los lados, en calidad de santos de su devoción, la humorista y bailarina Luisita Esteso, Mercedes Fifí, Matilde del Castillo, Antonia de Cachavera, tres jóvenes muchachos y un par de bellas admiradoras. A una de ellas, la barcelonesa María Antonia, va dedicada precisamente El Tonto. Esas santas quedarán expuestas en forma de postales, duraderas reproducciones sobre cartón resistente y fácilmente circulable.

En el prólogo de El encanto de la cama redonda, publicado en La Novela de Hoy, el 1 de diciembre de 1922, nos adelanta más 
fragmentos de su testamento. Con un delantal negro y unos labios perfilados, el pelo pegadisimo y una sonrisilla de niña picarona cuenta a su entrevistador, el director de la colección Artemio Precioso, que una gitana le predijo que moriría antes de los 25 . Y el 23 de febrero de 1922 se cumpliría, eso dice también, ese plazo. La edad de Retana siempre fue, como la de todo buen dandy, algo escurridiza. Con sus bien aprovechados 23 años, Retana impone una regla de oro. Nadie podrá verlo fiambre, todos deben conservar su imagen "decorativa, fragante y juvenil" (RETANA, 1922, p. 7). Una vez fiambre quería que le envolvieran en una túnica con los colores nacionales, cubierto de un sombrero cordobés y metido en un ataúd tapizado de retratos de cupletistas. Forrado más bien con postales y con imágenes de la prensa, cual mosaico de Disderi pero con rostros y torsos de cupletistas, Retana quería morir asfixiado con tanta mujer en pecado mortal y de refinado aroma. 
238 “iAmantes de papel!”: Las cupletistas y su performatividad a través de las postales fotográficas...

Fig. 11 - Altar con una estatuilla central de Afrodita o Venus en una hornacina, rodeada de fotografías y postales dedicadas de cupletistas, bailarinas, artistas de la escena, modelos y amigas, en el estudio compartido de la familia Romero de Torres en Córdoba

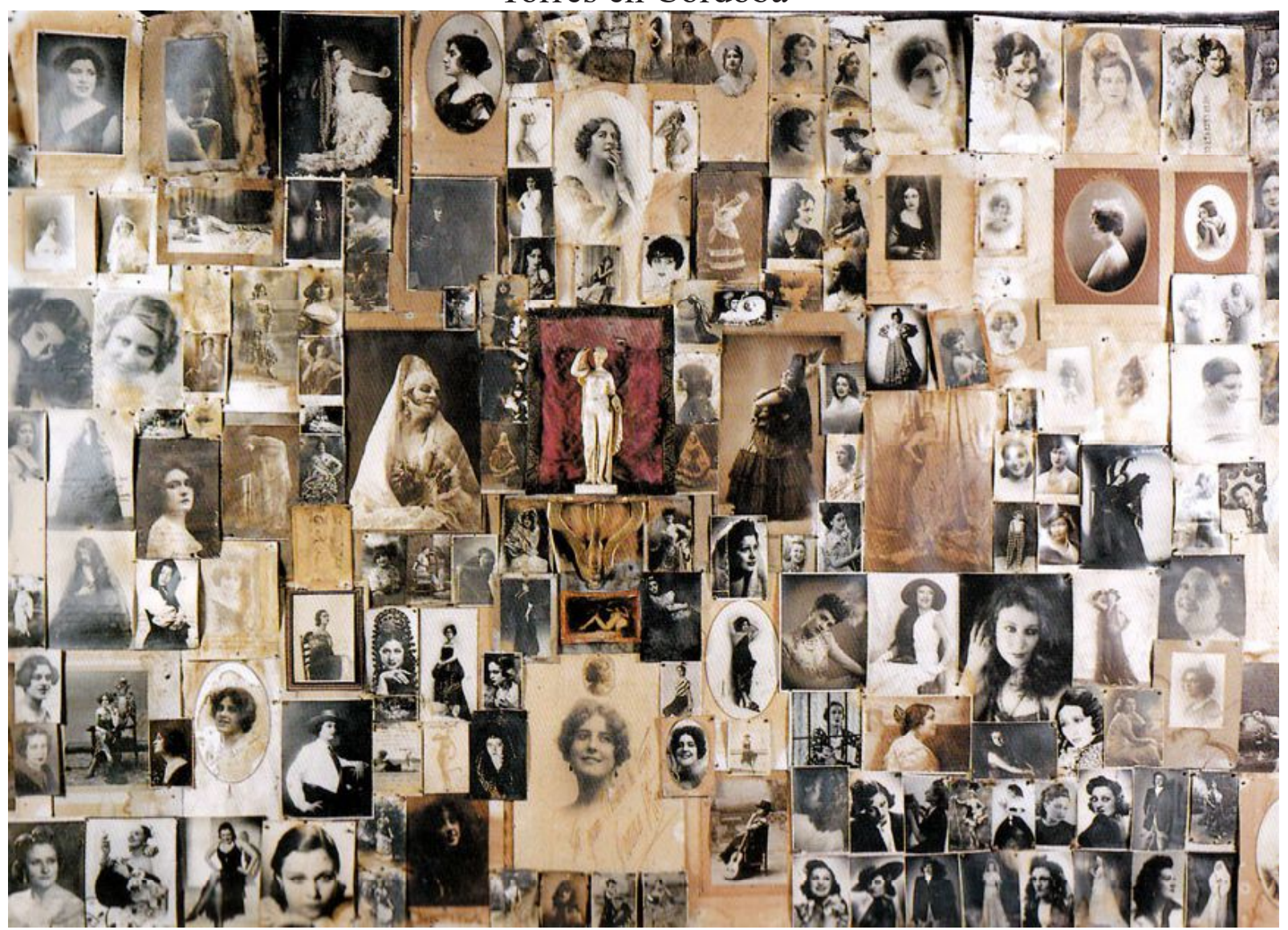

Fuente: Colección Romero de Torres, Junta de Andalucía.

Por su parte Julio Romero de Torres fue un gran coleccionista de postales junto a su hermano Enrique y su sobrino Rafael, también pintores que compartían su estudio en Córdoba. Conformarán también su propio altar, un nuevo estampario esta vez armado casi íntegramente por postales y fotografías de difícil delimitación, pero se encuentran muchas cupletistas y damas del cuché de la época, de las fiestas de La Parisiana, quizá del Fornos y de las calles de Madrid y de Córdoba, con la singularidad que todas ellas están dedicadas a cada uno de ellos, por las mismas cupletistas, entre ellas La Fornarina, Raquel Meller y La Argentinita, que demuestra que 
con ellas hubo algún tipo de contacto, de hecho, dos de ellas les hizo un retrato Julio Romero de Torres. El Altar de los Romero de Torres está presidido por una hornacina en la que hay una escultura griega o romana, similar a la Afrodita de Frejus o Venus Genetrix del Museo del Louvre, una diosa que varias veces pintó con su reflejo alegórico de la mujer mundana de su época. Las demás fotografías tienen poco de morenazas andaluzas de carnes prietas. Son retratos contemporáneos de toda la constelación de estrella del firmamento teatral y cancionero de su momento. Peinetas, flores, mantillas, sombreros imposibles, patillas enroscadas sobre sí mismas, desacato e imaginación... Las mil y una posibles poses de las mujeres empoderadas que encontraban en sus autorretratos un campo de juegos infinito para mostrarse con límites difusos, juguetonas, diversas, empoderadas.

\section{Mujeres-postal. Bailan, cantan y tiran postales}

Además de todos estos altares, ya en los años veinte y treinta se sucedieron varias revistas musicales en las que la mujer postal era la estrella. Dobles sentidos y amantes de papel. Por ejemplo, Las niñas de mis ojos, un pasatiempo cómico-lírico escrito por Manuel Fernández Palomero (1927) con música de Francisco Alonso, que incluía composiciones de jazz y un decorado con un "fantástico salón modernista, representando un Gabinete Clínico-Eléctrico [...] una rueda-volante de una máquina eléctrica [...] círculos de bombillas han de encenderse, por grupos de color, cuando gira la rueda-volante [...] aparato de dar corrientes eléctricas en la parte del cuerpo que se desee" (FERNÁNDEZ PALOMERO, 1927, p. 56). Desfilan por 
240 “iAmantes de papel!”: Las cupletistas y su performatividad a través de las postales fotográficas...

el escenario "Niñas Radio" con antenas, ondas y auriculares de casco, fumando con largas boquillas de ámbar cigarrillos aromáticos (FERNÁNDEZ PALOMERO, 1927, p. 78) y cuatro "HombresAltavoz" provistos de altavoces repartidos en distintos sitios del patio de butacas (FERNÁNDEZ PALOMERO, 1927, p. 78-79). También en otra escena aparecen chicas francesas bailando el shimmy "ataviadas con indumentaria con indumentaria de tarjeta postal parisina" (FERNÁNDEZ PALOMERO, 1927, p. 59). Estas mujerespostal bailan, cantan y tiran postales al público. Son las chicas de la casa de Madame Chupetín, las señoritas anunciadoras que van a repartir las tarjetas picantes. El baile, con aires de charlestón es muy americano, pero la imagen de las mujeres postal es netamente parisina, una mezcla muy años veinte, expatriados invadiendo Europa y fascinando a los españoles. Cosmopolitismo, transgresión y peligrosidad. Las chicas de la casa de Madame Chupetín cantan "Adorables muñequitas de París": Adorables muñequitas de París/ mensajeras de placer y de ilusión/ sus encantos a ofrecer vienen aquí/ con su alegre travesura y sansafón, La, la."

Mientras bailan, una de ellas, Mimí, las dirige, siguen bailando el shimmy y tirando postales al público, continuando su canción:

Si te da vergüenza mirarme en la calle/ llévame escondida, $\mathrm{y}$, al irte a acostar,/ mírame a los ojos, bésame en la boca/ y verás los goces que te hago soñar./ Nunca me desprecies si es que eres casado,/ pues a tu señora bien puede agradar/ ver que por mi causa esa noche cuenta/ con algo muy bueno que le va a gustar. (FERNÁNDEZ PALOMERO, 1927, p. 59-60). 
Estas amantes furtivas se harán en 1934 Las insaciables, y en 1935 Mujeres de Fuego. Las insaciables es una historieta cómicovodevilesca de Joaquín Vela y Enrique Sierra con música de Jacinto Guerrero. En las anotaciones del $n^{0} 8$ de la música, cuadro noveno, se indica la acción performativa de la vedette y las vicetiples con las postales entre el público:

La Vedette, vistiendo un traje fantástico, canta unos couplets, bajando al patio de butacas y dedicando cada letra a un espectador distinto, al propio tiempo que entrega al público retratos suyos con un autógrafo. En el último estribillo salen -también por el público- las vicetiples, con estilazos trajes de Botones, y reparten retratos igualmente. (VELA; SIERRA, 1934, p. 53).

Y ya en el 1935, las Mujeres de Fuego, con libreto de José Muñoz Román y Emilio González del Castillo y música del maestro Alonso, además de la danza apache y un coro de cigarreras, de nuevo las postales tomaban protagonismo. En un determinado momento, una de las vedettes bajaba al patio de butacas y hacía una fotografía al público, fotografía que al final se proyectaba en el escenario. De nuevo el público actor, la tecnología en las escenografías, y la postal de la vedette, cupletista o bailarina que se regala al respetable. Esta pieza, Mujeres de Fuego, fue famosa porque construía a unos hombres completamente ridículos y extravagantes frente a unas damas poderosas, que reflejaba ese miedo del público burgués de ser apartado de las instituciones políticas y profesionales de las que iban accediendo paulatinamente la mujer en esta época. Muñecas de París, insaciables y de fuego, las mujeres estaban muy empoderadas, 
242 “iAmantes de papel!": Las cupletistas y su performatividad a través de las postales fotográficas...

con las obvias contradicciones que también obviamente no nos dejaron seguir indagando.

\section{Conclusiones}

Todas las postales e infinitas imágenes de cupletistas y estrellas creadoras son un maravilloso ejemplo de la realidad visual de este tiempo. Todo este imaginario apareció en la vida cotidiana y no solo pobló la vida corriente de la gente sino que sobrevoló cualquier otra producción cultural. Cada una fabricó un acontecimiento que atrapó en una postal y quedó durante décadas conformando un imaginario que en los años veinte permitirá a las nuevas generaciones de artistas, como Norah Lange, indagar el mundo posible más ricos, arriesgados y galantes. Desde la primera cupletista hasta la mujer postal, que baja de escena para materializar el sueño de la corporeización del deseo, hubieron de nacer generaciones de creadoras porveniristas quienes con sus arriesgadas performatividades dieron alas a la imaginación de sus seguidores y proto fans.

Todas plasmaron en esas postales la génesis de su propio personaje frente a la pertenencia a un clan. Explotaron los nuevos medios de reproducción mecánica ya no solo para hacerse ubicuas sino para construir su personaje público, para jugar con su mutante auto imagen, para resultar deseables y deseadas, para ser coleccionadas y pegadas con chinchetas en las paredes de todos en general y de unos tantos escritores y pintores claves en particular. 


\section{Referencias}

ANASTASIO, Pepa. Pisa con Garbo. El cuplé como performance. TRANS-Revista Transcultural de Música, Barcelona, n. 13, 2009. ISSN1697-0101.

BOUCHAUD, Émilie Marie. Polaire par elle-même. París: Editions Eugène Figuière, 1933.

BUSZEK, Maria-Elena. Representing “awarishness": burlesque, feminist transgression, and the 19th-century pin-up. German Brecht, European Readings, Cambridge, v. 43, n. 4, p. 141-162, Winter 1999.

BUTLER, Judith. Actos performativos y constitución de género: un ensayo sobre fenomenología y teoría feminista. Debate Feminista, Ciudad de México, n. 18, p. 296-314, 1998.

CLÚA, Isabel. Cuerpos de escándalo: celebridad femenina en el fin-de siècle. Barcelona: Icaria, 2016.

DAVIS, Tracy C. Actresses as working women: their social identity in Victorian culture. London: Routledge, 1991.

DE ZAMORA, José. Cuando Madrid era pequeño... ABC, Madrid, p. 21-23, 10 jul. 1955.

DURÁN, Gloria G. Dandysmo y contragénero. Murcia: CENDEAC, 2011.

FERÁNDEZ PALOMERO, Manuel. Las niñas de mis ojos. Comedias [S. l.], v. LIX, p. 55-94, 2 abr. 1927.

GÓMEZ DE LA SERNA, Ramón. Automoribundia (1888-1948). Buenos Aires: Editorial Sudamericana, 1948. 
244 “iAmantes de papel!": Las cupletistas y su performatividad a través de las postales fotográficas...

GÓMEZ DE LA SERNA, Ramón. Color de diciembre y otras cosas. Edición de Ricardo Fernández Romero. Valenciana de la Concepción-Sevilla: Editorial Renacimiento, 2018.

GÓMEZ DE LA SERNA, Ramón. El desahucio a la vista. Escritos sobre fotografía (1908-1954). Introducción y edición de Humberto Huergo Cardoso. Madrid: Casimiro Libros, 2020.

GÓMEZ DE LA SERNA, Ramón. Ismos. Madrid: Biblioteca Nueva, 1931.

GÓMEZ DE LA SERNA, Ramón. Obras Completas XIX. Retratos y biografías IV. Biografías de escritores (1930-1953). Edición dirigida por Ioana Zlotescu. Barcelona: Círculo de Lectores/Galaxia Gutenberg, 2002.

GONZÁLEZ REYERO, Susana. La fotografía en la arqueología española (1860-1960): 100 años de discurso de la imagen. Madrid: Real Academia de la Historia. Universidad Autónoma, 2007.

HARO TECGLEN, Eduardo. El niño republicano. Madrid: Suma de letras, 2000.

LA CANTANTE más fea del mundo. Revista Alrededor Del

Mundo, Barcelona, n. 304, p. 201, ed. 30 mar. 1905.

LA CORRESPONDENCIA DE ESPAÑA. Madrid: La Correspondencia, 1859-1925. Año: 1920, 17 sep.

LANGE, Norah. 45 días y 30 marineros. Buenos Aires: InterZona editora, 2015.

MUNDO GRÁFICO. Lisboa: ed. com. Artur Portela, 1901-1959. Año: 1920.

NIETO DE MOLINA, Enrique. Tertulias de artistas. La del Colo- 
nial. Cómico, Madrid, v. 136, p. 6-7, oct. 1912.

PINTÓ, Alfonso. La tarjeta postal. Estética e historia. Barcelona: Producciones Editoriales del Nordeste, 1953.

RETANA, Álvaro. El encanto de la cama redonda. Madrid: Sucesores de Rivadeneyra, 1922. (Colección La Novela de Hoy, dirigida por Artemio Precioso, 1 dic. 1922).

RETANA, Álvaro. Historia del arte frívolo. Madrid: Editorial Tesoro, 1964.

SÁNCHEZ SÁNCHEZ, Isidro; VILLENA ESPINOSA, Rafael. La tarjeta postal en la historia de España. En: RIEGO AMÉZAGA, Bernardo (ed.). España en la tarjeta postal. Un siglo de imágenes. Madrid-Barcelona: Lunwerg, 2010. p. 11-52.

SOLOMON-GODEAU, Abigail. The legs of the countess. October, Boston, n. 39, p. 65-108, 1986.

VELA, Joaquín; SIERRA, Enrique. Las insaciables. Historieta cómico-vodevilesca. Música del Maestro Jacinto Guerrero. Madrid: Sociedad General de Autores de España, 1934.

ZUÑIGA, Ángel. Una historia del cuplé. Barcelona: Editorial Barna, 1954. 